УДК 633.522: 631.53.048: 631.526.3

DOI https://doi.org/10.32848/agrar.innov.2021.10.13

\title{
УПРАВЛІННЯ ПРОДУКТИВНІСТЮ РОСЛИН КОНОПЛІ ВУЗЬКОРЯДНИХ ПОСІВІВ ЗА КІЛЬКІСТЮ НАСІНИН, НОРМОЮ ВИСІВУ ТА СОРТОВИМ ФАКТОРОМ
}

\author{
СУЧЕК В.М. - аспірант \\ https://orcid.org/0000-0001-6738-6284 \\ Заклад вищої освіти «Подільський державний університет»
}

Постановка проблеми. У монографії «Біологія формування насіннєвої продуктивності конопель» М.Д. Мигаль зазначає, що «історично коноплярство розвивалося за пріоритетом у напрямі отримання волокна, що в усі часи користувалось і користується особливо великим попитом. Коноплі на товарне насіння не вирощували. Олію виробляли 3 насіння, яке залишалося після посіву. Наукова селекція на перших етапах свого розвитку також була спрямована насамперед на підвищення врожайності волокна і його якості. У результаті так сталося, що волокнистість стебла конопель досліджена значно більшою мірою, ніж насіннєва продуктивність» [1]. Автор висвітлює цілу низку наукових напрямів досліджень біологічного характеру, спрямованих на виведення нових сортів із підвищеною насіннєвою продуктивністю рослин коноплі.

Нині уже створено низку сортів однодомних конопель, які витіснили дводомні, цим забезпечили можливість збирання урожаю механізовано, як на волокно, так і на насіння. Відповідно, сьогодні актуальними є питання технологічного характеру, куди входить оцінка окремих факторів та підбір кращих біологічних чинників, тобто сортів на результативну ознаку насіннєву продуктивність рослин коноплі.

Аналіз останніх досліджень та публікацій. Сфера використання конопель постійно розширюється, відповідно розширюється територіально і зона вирощування цієї культури. Важливою стає доцільність сьогодні використання конопель не тільки на волокно, але і на насіння. Розпочинаючи 3 70-х років минулого століття багатьох привабило насіння, як об'єкт досліджень і як продукт споживання. Останнім часом продукція з насіння конопель все більше знаходить широке споживання та застосування [2, 3, 4, 5]. У Канаді коноплі культивують як зернову олійну культуру. Стебла при цьому є побічною продукцією. Проте сьогодні недостатньо досліджень технологічного характеру щодо управління продуктивністю коноплі за кількістю насінин на рослині. Відомо, що у багатьох сільськогосподарських культур озерненість рослин залежить від двох факторів в одних і тих же умовах, а саме від генотипу, тобто сорту, та від впливу технологічного фрактору. В авторитетних публікаціях зазначають, що в межах збільшення норми висіву насіння конопель забезпечує зростання урожайності соломи і зменшення насіннєвої продуктивності, а зниження норми висіву насіння, навпаки, - зростання урожайності насіння і зменшення урожаю волокнистої продукції [2].

У публікаціях трапляються дані про сівбу конопель із нормою висіву 0,9-2,4 млн схожих насінин на гектар звичайним рядковим способом, де за даними 1981-1984 рр. краща урожайність насіння була при нормі висіву 2,4 млн шт./га рядковим способом [2]. Г.І. Сенченко зазначає, що в минулому столітті незалежно від кількості внесених добрив коноплі висівали з нормою 6-6,5 млн схожих насінин на 1 га [6]. У публікаціях знаходимо, що недоцільно дотримуватись високої норми висіву насіння тоді, коли необхідно отримати урожай насіння та належну його якість. Далі рекомендовано сіяти широкорядно з нормою висіву насіння 1,2 млн шт./ га або вузькорядним способом з нормою 2,4 млн шт./га схожих насінин.

Проте у зв'язку з новими досягненнями в селекції однодомних сортів коноплі на основі багаторічних досліджень для одержання насіннєвої продукції залежно від попередника, родючості ґрунту, дози внесення добрив підхід до застосування норми висіву насіння має бути диференційований [2]. Важливо також звернути увагу на те, що сорти конопель сьогодні, які створені в Україні, різняться за напрямом використання. Вони поділяються на лубоволокнисті, двобічного використання та насіннєві. ВМ. Кабанець у своїй дисертаційній роботі звертає увагу на те, що норма висіву насіння конопель залежить від норми внесених добрив [2]. Відомі в літературних джерелах цитати про те, що норма висіву насіння раз і назавжди не має бути встановлена і рекомендована [7].

Мета досліджень - встановити залежність насіннєвої продуктивності рослин конопель посівних від сорту та диференційованих норм висіву насіння.

Матеріал та методика досліджень. Дослідження виконані впродовж 2018-2020рр. в Закладі вищої освіти «Подільський державний університет» в умовах Західного Лісостепу України.

У проведенні польових досліджень задіяні сорти коноплі посівної Інституту луб'яних культур Національної академії аграрних наук України: ЮСО-31, Гляна та Глесія.

Дослід організований за умови ширини міжрядь 15 см та варіантів норм висіву насіння - 1,2; 1,8; 2,4; 3,0; 3,6 млн шт./га. Тип ґрунту дослідних ділянок - чорнозем опідзолений на лесовидному суглинку.

Розміщення ділянок коноплі посівної - систематизоване ярусне. Кількість повторень - чотириразова. Загальна площа ділянки - $60 \mathrm{~m}^{2}$, облікової - $50 \mathrm{~m}^{2}$. Вибірка для біометричного аналізу шляхом підрахунку за параметрами кількості насінин на рослині становила 30 шт. рендомізовано відібраних. Для встановлення достовірності різниць застосовано порівняльно-статистичний аналіз на основі критерію Стьюдента за рівня надійної імовірності $\mathrm{P}_{0,95}$ та $\mathrm{P}_{0,99}$ [8]. 
Результати досліджень. Дослідження процесів формування урожаю актуальне для кожної сільськогосподарської культури, оскільки це дає можливість встановити ступінь залежності компонентів урожайності від факторів впливу. Зокрема, як технологічних і біологічних, так і фракторів вегетації. Сучасний розвиток світових агротехнологій передбачає створення оптимальних умов фрормування агрофітоценозу задля забезпечення реалізації біологічного потенціалу рослин. Біологічний потенціал як норма закономірності залежить від реалізації продуктивності рослин за двома складовими частинами: кількість зерен на рослині та маса зернівки. Інтегральний показник цих складових частин забезпечує параметр, а саме продуктивність однієї рослини. Відомо, що за сучасних рівнів урожайності зернових культур норми висіву насіння мають вагоме значення за впливом на параметр кількість зерен колоса, рослини [9]. Досить значна увага в наукових дослідженнях приділяється залежності реалізації цих складових елементів продуктивності та урожайності як показникам біологічного фрактору. Виведення нових сортів знову і знову ставить завдання пошуку забезпечення умов технологічних щодо оптимізації у забезпеченні реалізації їх біологічного потенціалу $[10,11]$. Щодо культури коноплі ці питання також залишаються актуальними.

Отримані нами результати досліджень доводять, що важливим фрактором впливу на фрормування продуктивності рослин коноплі за кількістю насінин $є$ умови агрофітоценозу, які створюються нормами висіву насіння за ширини міжряддя $15 \mathrm{~cm}$, і значна роль належить сорту, або сортовому генотипу.

Аналіз даних 2018 р. представлений такими результатами: по сорту ЮСО-31 встановлена закономірність зниження продуктивності рослин за показником кількості насінин на рослину при збільшенні норми висіву насіння. Зокрема, при нормі висіву 1,2 млн шт./га озерненість рослин коноплі становила 56,5 1,32, при нормі

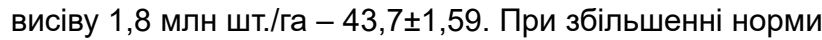
до 2,4 млн шт./га кількість насінин на рослині була

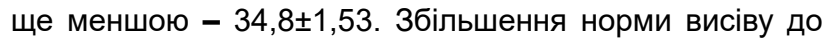
3,0 млн шт./га спричиняло подальше зменшення кількості насінин на одній рослині, відповідний показник становив $28,5 \pm 1,20$, і при збільшенні норми до 3,6 млн шт./га продуктивність рослини за кількістю насінин зменшилася ще на 3,2 шт., за наслідком чого показник становив $25,3 \pm 1,05$. За порівняння даних першої та другої норми висіву різниця 12,8 шт. істотна, критерій $t_{\phi}-6,2$ $>\mathrm{t}_{0,01}-2,68$. При порівнянні даних другої та третьої норми висіву насіння різниця становить 8,9 при $t_{\phi}-4,0$ $>\mathrm{t}_{0,01}-2,68$. Це свідчить, що за норми висіву насіння 2,4 млн шт./га кількість насінин на рослині зменшилася істотно до 34,8 шт. При нормі висіву 3,0 млн шт./га кількість насінин стала ще меншою, тобто продуктивність рослини знизилася. Різниця 6,3 істотна за порівняння до попередньої норми висіву. Встановлено $t_{\phi}-3,2>$ $\mathrm{t}_{0,01}-2,68$. I за умови норми висіву насіння 3,6 млн шт./ га продуктивність рослини коноплі стала меншою ще на 3,2 насінини, різниця істотна $\mathrm{t}_{\mathrm{\phi}}-2,1>\mathrm{t}_{0,05}-2,01$ (табл. 1).

Щодо сорту Гляна за першої норми висіву насіння 1,2 млн шт./га встановлено найбільше значення показника 83,8 шт. насінин на рослину. Збільшення норми висіву насіння до 1,8 млн шт./га також спричинило до зменшення показника $-61,0$ шт. насінин на рослину. Різниця 22,8 істотна на рівні значущості похибки $1 \%$, тобто $t_{\phi}-10,2>t_{0,01}-2,68$. За наступної норми висіву 2,4 млн шт./га показник продуктивності рослини становив 47,5 шт. нас. на рослину. Це менше порівняно до попередньої норми висіву на 13,5 шт., що відповідно істотно, $t_{\phi}-7,2>t_{0,01}-2,68$. Збільшення норми висіву насіння до 3,0 млн шт./га спричиняло подальше зниження цього показника, де він становив 38,6 шт., різниця $-8,9$ шт. при $t_{\phi}-5,1>t_{0,01}-2,68$. За норми висіву насіння 3,6 млн шт./га продуктивність рослин за кількістю насінин на рослині становила 32,8 шт., що менше за дані норми висіву 3,0 млн шт./га на 5,8 шт., різниця істотна $\mathrm{t}_{\phi}-3,8>\mathrm{t}_{0,01}-2,68$.

По сорту Глесія закономірність аналогічна. За норми висіву насіння 1,2 млн шт./га показник був на рівні 89,4 шт. на рослину. При збільшенні норми висіву насіння до 1,8 млн шт./га продуктивність за цим показником істотно зменшилась у рослин на 24,5 шт., де, $\mathrm{t}_{\mathrm{\phi}}-11,7>\mathrm{t}_{0,01}-2,68$. Збільшення норми висіву насіння до 2,4 млн шт./га спричиняло подальше зменшення кількості насінин на 13,3 шт. при значеннях параметра останнього $51,6 \pm 1,19$. Різниця істотна $\mathrm{t}_{\phi}-7,4>\mathrm{t}_{0,01}-2,68$. За умови сівби нормою висіву насіння 3,0 млн шт./га параметр продуктивності становив 42,4 шт. насінин на рослину. Різниця 9,2 істотна при $\mathrm{t}_{\phi}-5,1>\mathrm{t}_{0,01}-2,68$. I за найбільшої норми висіву насіння 3,6 млн шт./га кількість насінин на рослині була найменшою 37,0 шт. Різниця становить 5,4 шт. при встановленому $\mathrm{t}_{\phi}-3,1>\mathrm{t}_{0,01}-2,68$.

Далі висвітлюємо аналіз даних у порівнянні продуктивності сортів. У 2018 р. при нормі висіву 1,2 млн шт./га кількість насінин на рослину у сорту Гляна становила

Залежність кількості насінин 1 рослини конопель посівних від впливу норм висіву насіння та сорту за ширини міжрядь 15 см, шт., 2018 р.

\begin{tabular}{|c|c|c|c|c|}
\hline \multirow{2}{*}{$\begin{array}{c}\text { Норми висіву насін- } \\
\text { нялмн шт./га, фактор А }\end{array}$} & \multicolumn{3}{|c|}{ Сорти, фактор В } & $\begin{array}{c}\text { Середнє } \\
\text { по фактору А }\end{array}$ \\
\hline 1,2 & $56,5 \pm 1,32$ & Гляна & Глесія & 76,6 \\
\hline 1,8 & $43,7 \pm 1,59$ & $83,8 \pm 1,80$ & $89,4 \pm 1,59$ & 56,5 \\
\hline 2,4 & $34,8 \pm 1,53$ & $61,0 \pm 1,32$ & $64,9 \pm 1,36$ & 44,6 \\
\hline 3,0 & $28,5 \pm 1,20$ & $47,5 \pm 1,32$ & $51,6 \pm 1,19$ & 36,5 \\
\hline 3,6 & $25,3 \pm 0,95$ & $38,6 \pm 1,13$ & $42,4 \pm 1,34$ & 31,7 \\
\hline Середнє по фрактору В & 37,8 & $32,8 \pm 1,05$ & $37,0 \pm 1,11$ & 49,2 \\
\hline
\end{tabular}


$83,8 \pm 1,80$ шт., у сорту ЮСО-31 цей показник був меншим - 56,5 $\pm 1,32$ шт. Різниця 27,3 істотна, $t_{\phi}-12,2>$ $\mathrm{t}_{0,01}-2,68$. При нормі висіву насіння 1,8 млн шт./га між даними цих сортів різниця була 17,3 насінини при встановленому $t_{\phi}-8,4>t_{0,01}-2,68$, далі за норми висіву насіння 2,4 млн шт./га розходження даних було в межах 12,7 шт. насінин, що також істотно $\mathrm{t}_{\mathrm{\phi}}-6,3>\mathrm{t}_{0,01}-2,68$. $3 \mathrm{a}$ умови норм висіву насіння 3,0 млн шт./га різниця даних кількості насінин на рослині відносно цих сортів у порівнянні становила 10,1 шт. при встановленому $t_{\phi}-6,1>$ $\mathrm{t}_{0,01}-2,68$. I за порівняння даних показників при нормі висіву насіння 3,6 млн шт./га показник у сорту Гляна

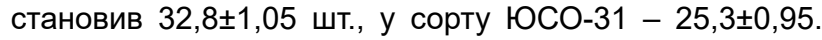
Різниця також істотна на рівні значущості похибки $1 \%$, $\mathrm{t}_{\phi}-5,3>\mathrm{t}_{0,01}-2,68$. Отже, за всіх варіантів порівнянь значення кількості насінин однієї рослини за даними 2018 p. завжди були більшими у сорту Гляна.

Аналіз даних у порівнянні сортів Гляна та Глесія, де показники кількості насінин на 1 рослині відповідно становлять при нормі висіву насіння 1,2 млн шт./га, $83,8 \pm 1,8$ та 89,4 $\pm 1,59$. Різниця 5,6, де $t_{\phi}-2,3>t_{0,05}-2,01$. За аналогічного порівняння даних норми висіву насіння 1,8 млн шт./га показники сортів Гляна та Глесія $61,0 \pm 1,32$ та $64,9 \pm 1,36$, різниця 3,9 істотна на рівні значущості похибки 5\%, де $\mathrm{t}_{\phi}-2,1>\mathrm{t}_{0,05}-2,01$. За умови норми висіву насіння 2,4 млн шт./га різниця даних сортів 47,5 $\pm 1,32$ та $51,6 \pm 1,19$ становить 4,1 що істотно на рівні значущості похибки $5 \%, \mathrm{t}_{\phi}-2,3>\mathrm{t}_{0,05}-2,01$. За умови норми висіву насіння 3,0 млн шт./га різниця між даними $38,6 \pm 1,13$ та $42,4 \pm 1,34-3,8$ шт. насінин істотна $t_{\phi}-2,2>t_{0,05}-2,01$. І за порівняння даних $32,8 \pm 1,05$ та $37,0 \pm 1,11$ сортів Гляна та Глесія при висіві насіння 3,6 млн шт./га різниця становить 4,2 при встановленому $\mathrm{t}_{\phi}-2,8>\mathrm{t}_{0,01}-2,68$.

Отже, порівняння даних кількості насінин на рослині сортів коноплі за всіх норм висіву насіння показує, що у 2018 р. найвищі показники були у сорту Глесія, дещо істотно менші за значення у сорту Гляна і найменші показники за всіх норм висіву насіння були встановлені для сорту ЮСО-31.

У 2019 р. за впливом норм висіву насіння щодо сорту коноплі ЮСО-31 при нормі висіву насіння 1,2 млн шт./га показник кількості зерен на рослині становив $54,5 \pm 1,10$ шт. При збільшенні норми висіву насіння до 1,8 млн шт./га значення цього показника становило 44,6 \pm 1,11 шт. Різниця істотна 9,9 шт. при встановленому $t_{\phi}-6,3>t_{0,01}-2,68$. Збільшення норми висіву насіння до 2,4 млн шт./га забезпечило меншу кількість насіння на рослині, відповідно показник стано-

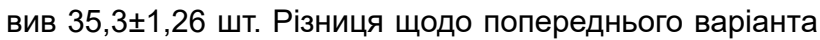
норми висіву насіння істотна 9,3 при $\mathrm{t}_{\phi}-5,5>\mathrm{t}_{0,01}-2,68$. Збільшення норми висіву насіння до 3,0 млн шт./га спричиняло до подальшого зменшення цього показника порівняно до попереднього варіанта на 6,2 при встановленому $t_{\phi}-3,4>t_{0,01}-2,68$, відповідно різниця істотна. I за норми висіву насіння 3,6 млн шт./га. кількість насінин на одній рослині була найменшою - 24,8 шт. Порівняно до попередньої норми висіву менше на 4,3 насінини. Встановлена істотна різниця при значущості похибки $5 \%, \mathrm{t}_{\phi}-2,6>\mathrm{t}_{0,5}-2,01$ ( табл. 2).

У 2019 р. аналіз даних сорту Гляна показав, що за норми висіву 1,2 млн шт./га показник становив $79,0 \pm 1,73$ а при нормі висіву насіння 1,8 млн шт./га

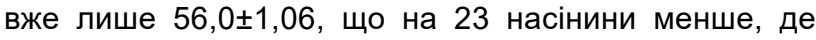
$t_{\phi}-11,3>t_{0,01}-2,68$. Збільшення норми висіву насіння до 2,4 млн шт./га забезпечило зменшення показника

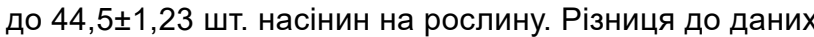
попередньої норми висіву, істотна і становила 11,5 шт., де критерій Стьюдента на рівні $\mathrm{t}_{\phi}-7,1>\mathrm{t}_{0,01}-2,68$. Наступна норма висіву 3,0 млн шт./га виділяється значенням $36,8 \pm 0,94$, що менше від даних попередньої норми висіву насіння на 7,7 шт. Різниця істотна, $\mathrm{t}_{\phi}-5,0$ $>\mathrm{t}_{0,01}-2,68$. При збільшенні норми висіву насіння до 3,6 млн шт./га показник був найменшим - 32,2士1,09, де менший показник до даних попередньої норми висіву насіння на 4,6 шт. Істотність різниці доведена, $\mathrm{t}_{\phi}-3,2$ $>\mathrm{t}_{0,01}-2,68$.

Аналіз даних отриманих в результаті досліджень по сорту Глесія свідчить, що у 2019 р. за норми висіву насіння 1,2 млн шт./га кількість насінин на рослині становила 83,9 шт. За норми висіву 1,8 млн шт./га їх кількість зменшилась до 60,3 шт. Різниця 23,6 шт. при встановленому $t_{\phi}-11,5>t_{0,01}-2,68$. Збільшення норми висіву насіння до 2,4 млн шт./га спричиняло зменшення кількості насінин на рослині до 48,5 шт. Відповідно до попередньої норми висіву різниця була істотна і становила 11,8 , де $t_{\phi}-5,6>t_{0,01}-2,68$. Збільшення норми висіву насіння до 3,0 млн шт./га також призводило до подальшого зменшення продуктивності рослин коноплі за кількістю насінин, у результаті чого показник становив 39,8 шт. Зменшення даних становило 8,7 шт. при критерії $\mathrm{t}_{\phi}-5,4>\mathrm{t}_{0,01}-2,68$. I за норми висіву 3,6 млн шт./га середньо статистичний показник становив 33,0 шт. При порівнянні до попередньої норми висіву різниця стано-

Залежність кількості насінин 1 рослини конопель посівних від впливу норм висіву насіння та сорту за ширини міжрядь 15 см, шт., 2019 р.

\begin{tabular}{|c|c|c|c|c|}
\hline $\begin{array}{c}\text { Норми висіву насін- } \\
\text { ня,млн шт./га, фактор А }\end{array}$ & \multicolumn{3}{|c|}{ Сорти, фактор В } & $\begin{array}{c}\text { Середнє } \\
\text { по фактору А }\end{array}$ \\
\hline 1,2 & ЮСО-31 & Гляна & Глесія & 72,5 \\
\hline 1,8 & $54,5 \pm 1,10$ & $79,0 \pm 1,73$ & $83,9 \pm 1,32$ & 53,6 \\
\hline 2,4 & $44,6 \pm 1,11$ & $56,0 \pm 1,06$ & $60,3 \pm 1,58$ & 42,8 \\
\hline 3,0 & $35,3 \pm 1,26$ & $44,5 \pm 1,23$ & $48,5 \pm 1,37$ & 35,2 \\
\hline 3,6 & $29,1 \pm 1,31$ & $36,8 \pm 0,94$ & $39,8 \pm 0,83$ & 30,0 \\
\hline Середнє по фрактору В & $24,8 \pm 1,06$ & $32,2 \pm 1,09$ & $33,0 \pm 1,98$ & 46,8 \\
\hline
\end{tabular}


вить 6,8 при $\mathrm{t}_{\phi}-3,2>\mathrm{t}_{0,01}-2,68$. Відповідно, кожна норма висіву насіння за ії збільшення спричиняла зменшення кількості насінин на рослині коноплі посівної.

Щодо порівняння різниць за результатами досліджень 2019 р. між даними сортів ЮСО-31 - Гляна доведено, що за умови норми висіву насіння 1,2 млн шт./га показники відповідно до сортів становлять $54,5 \pm 1,10$ та $79,0 \pm 1,73$. Різниця 24,5 була істотна на рівні значущості похибки $1 \%, \mathrm{t}_{\phi}-12,0>\mathrm{t}_{0,01}-2,68$. Порівняння даних за

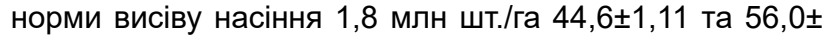
1,06 забезпечує істотну різницю 11,4 при встановленому $t_{\phi}-7,4>t_{0,01}-2,68$. Наступне порівняння даних отрима-

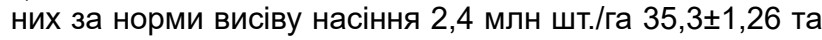
$44,5 \pm 1,23$ різниця даних становить 9,2, що істотно на рівні значущості похибки $1 \%, \mathrm{t}_{\phi}-5,2>\mathrm{t}_{0,01}-2,68$. За умови норми висіву насіння 3,0 млн шт./га при порівнянні даних

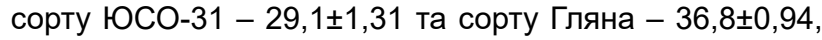
різниця була істотна 7,7 на рівні $1 \%$ похибки, $\mathrm{t}_{\phi}-4,8>$ $\mathrm{t}_{0,01}-2,68$. I при порівнянні даних за умови варіанта норми висіву насіння 3,6 млн шт./га відповідно до сортів отримані дані $24,8 \pm 1,06$ та $32,2 \pm 1,09$, різниця становить 7,4 при статистичних розрахунках $\mathrm{t}_{\phi}-4,9>\mathrm{t}_{0,01}-2,68$.

При статистичному порівнянні даних сортів Гляна та Глесія за норми висіву насіння 1,2 млн шт./га 79,0 $\pm 1,73$ та $83,0 \pm 1,32$, різниця становить 4,9 , що істотно на рівні значущості похибки $5 \%, \mathrm{t}_{\mathrm{\phi}}-2,3>\mathrm{t}_{0,05}-2,01$. За умови норми висіву насіння 1,8 млн шт./га показники були дещо мен-

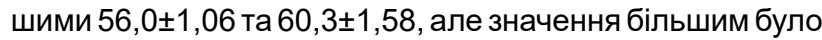
у сорту Глесія. Різниця 4,3 істотна, $\mathrm{t}_{\phi}-2,3>\mathrm{t}_{0,05}-2,01$. При порівнянні даних $44,5 \pm 1,23$ та $48,5 \pm 1,37$ за умови норми висіву насіння 2,4 млн шт./га різниця 4,0 доведена статистично на рівні похибки $5 \%, \mathrm{t}_{\phi}-2,2>\mathrm{t}_{0,05}-2,01$. На варіанті порівняння за норми висіву насіння 3,0 млн шт./га показники становлять $36,8 \pm 0,94$ та $39,8 \pm 0,83$, різниця 3,0 істотна $t_{\phi}-2,4>t_{0,05}-2,01$. I за норми висіву насіння

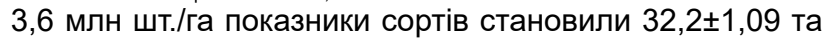
$33,0 \pm 1,98$ різниця даних не істотна, що становить виняток із встановленої закономірності.

Отже, встановлена закономірність, за якою найбільша кількість насіння на рослині коноплі була у рослин сорту Глесія, поступається йому сорт Гляна, а сорту Гляна сорт ЮСО-31. Виняток був при порівнянні за норми висіву насіння 3,6 млн шт./га між даними сортів коноплі Гляна та Глесія, де не встановлено статистичної різниці щодо кількості насінин на рослині.

У 2020 р. по сорту ЮСО-31 різниця між даними норм висіву 1,2 млн шт./га - 54,8 $\pm 1,45$ шт. насінин на рос-

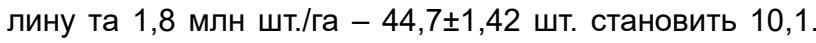
Розходження істотне, $\mathrm{t}_{\phi}-5,0>\mathrm{t}_{0,01}-2,68$. Порівняння даних норми висіву 1,8 млн шт./га та норми висіву насіння 2,4 млн шт./га показує різницю 8,2 шт. при встановленому $t_{\phi}-4,5>t_{0,01}-2,68$. Збільшення норми висіву насіння до 3,0 млн шт./га забезпечило показник кількості насінин на рослину 30,8 шт. Різниця до даних попередньої норми висіву істотна на рівні похибки 1,0\% і становить 5,7, де $\mathrm{t}_{\phi}-3,5>\mathrm{t}_{0,01}-2,68$. Збільшення норми висіву до 3,6 млн шт./га спричинило подальше зменшення показника до 27,4 шт., що менше від даних попередньої норми висіву на 3,4 шт. В результаті статистичного розрахунку різниця істотна на $5,0 \%$ рівні значущості похибки $-\mathrm{t}_{\phi}-2,3>\mathrm{t}_{0,05}-2,01$ (табл. 3).

Аналіз даних по сорту Гляна показує, що при порівнянні показників норм висіву $1,2 \mathrm{mлн} \mathrm{шт./га} \mathrm{та}$ 1,8 млн шт./га встановлена різниця даних $21,5, \mathrm{t}_{\phi}-10,5$ $>\mathrm{t}_{0,01}-2,68$, що свідчить про істотність. При наступному порівнянні параметрів показників норм висіву насіння 1,8 та 2,4 млн шт./га різниця була істотна і становила $13,7, \mathrm{t}_{\phi}-6,7>\mathrm{t}_{0,01}-2,68$. Порівняння даних норм висіву насіння 2,4 та 3,0 млн шт./га забезпечило різницю 6,8 шт., що істотно на рівні значущості похибки 1,0\%, $t_{\phi}-3,8>t_{0,01}-2,68$. При висіві насіння 3,6 млн шт./га показник кількості насінин на рослину був меншим на 5,1 порівняно даних норм висіву насіння 3,0 млн шт./га. Різниця встановлена істотна, $\mathrm{t}_{\phi}-2,6>\mathrm{t}_{0,05}-2,01$.

Для сорту Глесія закономірність така, яка показана по сорту Гляна. За порівняння даних норм висіву 1,2 та 1,8 млн шт./га різниця становила 22,2 шт. Відповідно кількість насінин на одну рослину зменшилась за більшої із цих норм висіву. Істотність встановлена, $\mathrm{t}_{\phi}-11,3>$ $\mathrm{t}_{0,01}-2,68$. За наступного порівняння даних норм висіву насіння 1,8 та 2,4 млн шт./га різниця становить 14,0 шт., де $t_{\phi}-8,5>t_{0,01}-2,68$. Збільшення норм висіву насіння до 3,0 млн шт./га забезпечило зменшення кількості насінин на рослині до 44,7 шт., що менше порівняно до даних норм висіву 2,4 млн шт./га на 6,9 шт. насінин. Різниця істотна $t_{\phi}-4,6>t_{0,01}-2,68$. За найбільшої норми висіву 3,6 млн шт./га показник становив 40,3 шт. насінин, що відповідно менше за показник норми 3,0 млн шт./га. на 4,4 шт. насінин. Різниця істотна $\mathrm{t}_{\phi}-2,8>\mathrm{t}_{0,01}-2,68$.

Аналіз даних кількості насінин на рослині коноплі залежно сорту за 2020 р. показує, що при нормі висіву насіння 1,2 млн шт./га показники сортів ЮСО-31та Гляна становили $54,8 \pm 1,45$ та $83,1 \pm 1,49$. Різниця між даними становить 28,3 шт., що свідчить про значні розходження,

Залежність кількості насінин 1 рослини конопель посівних від впливу норм висіву насіння

Таблиця 3 та сорту за ширини міжрядь 15 см, шт., 2020 р.

\begin{tabular}{|c|c|c|c|c|}
\hline $\begin{array}{c}\text { Норми висіву насін- } \\
\text { ня,млн шт./га, фактор А }\end{array}$ & \multicolumn{3}{|c|}{ Сорти, фактор В } & $\begin{array}{c}\text { Середнє } \\
\text { по фактору А }\end{array}$ \\
\hline 1,2 & $54,8 \pm 1,45$ & Гляна & Глесія & 75,2 \\
\hline 1,8 & $44,7 \pm 1,42$ & $63,1 \pm 1,49$ & $87,8 \pm 1,45$ & 57,3 \\
\hline 2,4 & $36,5 \pm 1,17$ & $47,6 \pm 1,41$ & $65,6 \pm 1,32$ & 45,3 \\
\hline 3,0 & $30,8 \pm 1,13$ & $41,1 \pm 1,48$ & $51,6 \pm 1,00$ & 38,9 \\
\hline 3,6 & $27,4 \pm 1,00$ & $36,0 \pm 1,66$ & $44,7 \pm 1,13$ & 34,6 \\
\hline Середнє по фрактору В & 38,8 & 53,9 & $40,3 \pm 1,13$ & 50,3 \\
\hline
\end{tabular}


Залежність продуктивності коноплі за кількістю насінин на 1 рослині від впливу норм висіву насіння та сортового фактора за ширини міжрядь 15 см, шт. (середнє за 2018-2020 рр.)

\begin{tabular}{|c|c|c|c|c|}
\hline $\begin{array}{c}\text { Норми висіву насін- } \\
\text { ня,млн шт./га, фактор А }\end{array}$ & \multicolumn{3}{|c|}{ Сорти, фактор В } & $\begin{array}{c}\text { Середнє } \\
\text { по фактору А }\end{array}$ \\
\hline 1,2 & ЮСО-31 & Гляна & Глесія & 74,8 \\
\hline 1,8 & 55,3 & 82,0 & 87,0 & 55,8 \\
\hline 2,4 & 44,3 & 59,5 & 63,6 & 44,2 \\
\hline 3,0 & 35,5 & 46,6 & 50,6 & 36,9 \\
\hline 3,6 & 29,5 & 38,8 & 42,3 & 32,1 \\
\hline Середнє по фактору В & 25,8 & 33,7 & 36,8 & 48,8 \\
\hline
\end{tabular}

$\mathrm{t}_{\phi}-13,6>\mathrm{t}_{0,01}-2,68$. При порівнянні даних за норми висіву

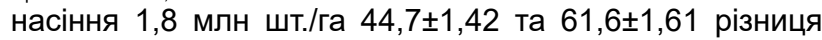
даних була 16,9 при встановленому $\mathrm{t}_{\phi}-8,4>\mathrm{t}_{0,01}-2,68$. За наступного порівняння при висіві 2,4 млн шт./га різницю даних сортів коноплі забезпечували параметри

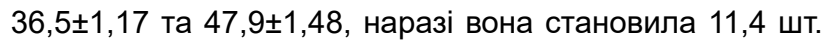
насінин при $t_{\phi}-6,0>t_{0,01}-2,68$. За умови збільшення норми висіву насіння до 3,0 млн шт./га при показниках $30,8 \pm 1,13$ та $41,1 \pm 1,0$ відповідно до сортів ЮСО-31 та Гляна різниця становила 10,3 при розрахунках $t_{\phi}-6,8$ $>\mathrm{t}_{0,01}-2,68$. І за норми висіву насіння $3,6 \mathrm{mлн} \mathrm{шт./га}$ різниця між даними сортів коноплі становила 8,6 при

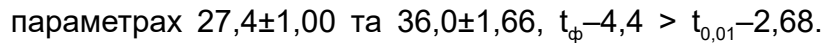
Результати аналізу свідчать про кращу насіннєву продуктивність рослин коноплі сорту Гляна порівняно сорту ЮСО-31.

При порівнянні даних кількості насінин на рослині коноплі між сортами Гляна - Глесія за норми висіву насіння 1,2 млн шт./га встановлені дані відповідно до сортів $83,1 \pm 1,49$ та $87,8 \pm 1,45$. Різниця була 4,7 при $t_{\phi}-2,3>t_{0,05}-2,01$. За умови норми висіву насіння 1,8 млн шт./га різниця між даними сортів при отриманих результатах $61,6 \pm 1,41$ та $65,6 \pm 1,32$ була незначною 4,0, але істотною, $\mathrm{t}_{\phi}-2,1>\mathrm{t}_{0,05}-2,013$ перевагою сорту Глесія. Порівняльний аналіз даних за норми висіву насіння 2,4 млн шт./га визначається даними $47,9 \pm 1,48$ та $51,6 \pm 1,00$, де встановлена різниця 3,7 при критерії Стьюдента $\mathrm{t}_{\phi}-2,1>\mathrm{t}_{0,05}-2,01$. Аналіз даних норми 3,0 млн шт./га характеризується різницею 3,6 при отриманих показниках $41,1 \pm 1,00$ та $44,7 \pm 1,13$ відповідно сортів Гляна та Глесія, де встановлено $t_{\phi}-2,4$ $>\mathrm{t}_{0,05}-2,01$. І за норми висіву насіння 3,6 млн шт./га різниця кількості насінин на рослині коноплі між сортами Гляна та Глесія була також істотна на користь більшого значення сорту Глесія. Встановлені показники $36,0 \pm 1,66$ та $40,3 \pm 1,13$ за різниці 4,3 при $t_{\phi}-2,1$ $>\mathrm{t}_{0,05}-2,01$.

Результати досліджень у середньому за період 2018-2020 років узагальнюють закономірність, при якій рослини коноплі за ширини міжрядь 15 см при збільшенні норм висіву насіння в межах варіантів 1,2; 1,$8 ; 2,4 ; 3,0 ; 3,6$ млн шт./га у сортів ЮСО-31, Гляна, та Глесія зменшують продуктивність за показником кількості насінин на одній рослині. Це стверджує ефективність в управлінні цим технологічним фактором параметрами індивідуальної продуктивності рослин коноплі (табл. 4).
Висновки. В середньому по досліду для фактора А відповідно до зазначених норм висіву насіння 1,2; 1,8; 2,$4 ; 3,0$ та 3,6 млн шт./га встановлені показники 74,8; 55,$8 ; 44,2 ; 36,9 ; 32,1$ шт. насінин на 1 рослину.

Найбільшу кількість насіння на 1 рослині при ширині міжрядь 15 см за всіх норм висіву насіння 1,2 млн шт./га; 1,8; 2,4; 3,0 та 3,6 млн шт./га забезпечував сорт коноплі Глесія, другий за продуктивністю сорт Гляна, і найменшу продуктивність забезпечив сорт коноплі ЮСО-31.

\section{СПИСОК ВИКОРИСТАНОÏ ЛІТЕРАТУРИ:}

1. Мигаль М.Д. Біологія формування насіннєвої продуктивності конопель: монографія. Суми: видавничий будинок «Еллада», 2015. 233 с.

2. Вировець В.Г., Баранник В.Г., Гілязетдінов Р.Н. та ін. Коноплі: монографрія; за ред. М.Д. Мигаля, В.М. Кабанця. Суми: видавничий будинок «Еллада», 2011. 384 c.

3. Farinon B., Molinari R., Costantini L., Merendino N. The seed of industrial hemp (Cannabis sativa L.): Nutritional Quality and Potential Functionality for Human Health and Nutrition. Nutrients. 2020. 12. P. 1935. DOI: https:// doi.org/10.3390/nu12071935.

4. Karus M.; Vogt D. European hemp industry: Cultivation, processing and product lines. Euphytica. 2004. 140. P. 7-12. DOI: https://doi.org/10.1007/ s10681-004-4810-7.

5. Vera C.L.; Hanks A. Hemp Production in Western Canada. J. Ind. Hemp. 2004. 9. P. 79-86. DOI: https:// doi.org/10.1300/J237v09n02_08.

6. Сенченко Г.И., Вировец В.Г., Горшкова Л.М. и др. Создание новых высокопродуктивных сортов однодомной конопли. Биологические особенности, технология возделывания и первичная обработка конопли. Глухов, 1982. Вып. 43. С. 3-12.

7. Лихочвор В.В., Проць Р.Р., Долєжал Я. Ячмінь. Львів: НВФ Українські технології, 2003. 88 с.

8. Доспехов Б.А. Методика полевого опыта. Москва: Агропромиздат, 1985. 351 с.

9. Гораш О.С., Климишена Р.І. Ячмінь: управління пивоварною якістю: монографія. Кам'янець-Подільський: ТОВ «Друкарня Рута», 2020. 260 с.

10. Мигаль М.Д., Конопля К.В., Рухленко В.М. Підвищення насіннєвої продуктивності конопель. Збірник наукових праць ННЦ «Інститут землеробства УААН». К., 2009. Вип. 3. С. 132-143.

11. Голобородько П.А., Коротя К.Я., Ситник В.П. та ін. Технологія вирощування конопель. Конопля. Суми: ВБ «Еллада», 2011. С. 172-215. 


\section{REFERENCES:}

1. Migal M.D. (2015) Biolohiia formuvannia nasinnievoi produktyvnosti konopel: monohrafiia. [Biology of hemp productivity formation: monograph]. Sumy: vydavnychyi budynok «Ellada», 233. [in Ukrainian]

2. Vyrovets V.G., Barannyk V.G., Giliazetdinov R.N. etc. (2011) Konopli: monohrafiia; za red. M.D. Mygal, V.M. Kabanets. [Hemp: monograph; for ed. M.D. Mygal, V.M. Kabanets]. Sumy: vydavnychyi budynok «Ellada», 384. [in Ukrainian]

3. Farinon B., Molinari R., Costantini L., Merendino N (2020) The seed of industrial hemp (Cannabis sativa L.): Nutritional Quality and Potential Functionality for Human Health and Nutrition. Nutrients, 12, 1935. DOI: https:// doi.org/10.3390/nu12071935.

4. Karus M.; Vogt D. (2004) European hemp industry: Cultivation, processing and product lines. Euphytica, 140, 7-12. DOI: https://doi.org/10.1007/ s10681-004-4810-7.

5. Vera C.L.; Hanks A. (2004) Hemp Production in Western Canada. J. Ind. Hemp, 9, 79-86. DOI: https:// doi.org/10.1300/J237v09n02_08.

6. Senchenko G.I., Virovets V.G., Gorshkova L.M. and others. (1982) Sozdanie novyh vysokoproduktivnyh sortov odnodomnoj konopli. [Creation of new highly productive varieties of monoecious hemp]. Biologicheskie osobennosti, tehnologija vozdelyvanija i pervichnaja obrabotka konopli - Biological features, cultivation technology and primary processing of hemp, Gluhov, 43, 3-12. [in Ukrainian]

7. Likhochvor V.V., Prots R.R., Dolezhal Ya. (2003) Yachmin. [Barley]. Lviv: NVF Ukrainski tekhnolohii, 88. [in Ukrainian]

8. Dospehov B.A. (1985) Metodika polevogo opyta [Methods of field experience]. Moskva: Agropromizdat, 351. [in Russian]

9. Gorash, O.S., Klymyshena, R.I. (2020). Yachmin: upravlinnia pyvovarnoiu yakistiu: Monohrafiia. [Barley: brewing of quality management: Monograph]. KamianetsPodilskyi: TOV «Drukarnia Ruta», 260. [in Ukrainian]

10. Migal M.D., Konoplia K.V., Rukhlenko V.M. (2009) Pidvyshchennia nasinnievoi produktyvnosti konopel. [Increasing the seed productivity of hemp]. Zbirnyk naukovykh prats NNTs «Instytut zemlerobstva $U A A N »-$ Collection of scientific works of ESC «Institute of Agriculture UAAS», 3, 132-143. [in Ukrainian]

11. Goloborodko P.A., Korotia K.Ya., Sytnyk V.P. etc. (2011) Tekhnolohiia vyroshchuvannia konopel. [Hemp growing technology]. Konoplia - Hemp. Sumy: VB «Ellada», 172-215. [in Ukrainian]

Сучек В.М. Управління продуктивністю рослин коноплі вузькорядних посівів за кількістю насінин нормою висіву та сортовим фрактором

Мета досліджень - встановити залежність насіннєвої продуктивності рослин конопель посівних від сорту та диференційованих норм висіву насіння.

Для узагальнення результатів дослідження та наукового обґрунтування мети застосовували такі методи: загальнонаукові (для визначення напряму дослідження, планування і закладки досліду); спеціальні (лабораторний - для визначення біометричних показників); математично-статистичний (для обробки експериментальних даних).
Результати. Встановлено, що при збільшенні норми висіву до 1,8 млн шт./га порівняно норми 1,2 млн шт./ га продуктивність рослин за кількістю насіння зменшилася на 25,4\%, за норми висіву насіння 2,4 млн шт./га порівняно норми 1,8 млн шт./га - на 20,8\%, за норми висіву насіння 3,0 млн шт./га порівняно до попередньої норми 2,4 млн шт./га - на 16,5\% і за норми висіву насіння 3,6 млн шт./га менше насіння на одній рослині було порівняно норми 3,0 млн шт./га - на 13,0\%. Також встановлено, що в роки досліджень за всіх норм висіву насіння сорти коноплі істотно відрізнялися між собою за продуктивністю, щодо кількості насінин на одній рослині. У середньому по фактору В за три роки досліджень продуктивність сортів коноплі посівної за параметрами кількості насінин на 1 рослині становила для сортів: ЮСО-31 - 38 шт., Гляна - 52 шт. і Глесія - 56 шт. Це також стверджує про результативність на рівні структури ДНК, як біологічного фактора до якого відносяться сучасні сорти коноплі посівної в управлінні насіннєвою продуктивністю рослин.

Висновки. У середньому по досліду для фрактору А відповідно до зазначених норм висіву насіння 1,2; 1,8; 2,$4 ; 3,0$ та 3,6 млн шт./га встановлені показники 74,8 ; 55,$8 ; 44,2 ; 36,9 ; 32,1$ шт. насінин на 1 рослину. Найбільшу кількість насіння на 1 рослині при ширині міжрядь 15 см за всіх норм висіву насіння 1,2 млн шт./га; 1,8; 2,4; 3,0 та 3,6 млн шт./га забезпечував сорт коноплі Глесія, другий за продуктивністю - сорт Гляна, і найменшу продуктивність забезпечив сорт коноплі ЮСО-31.

Ключові слова: конопля посівна, кількість насінин, норма висіву, сорт, ширина міжрядь, управління продуктивністю.

Suchek V.M. Management of hemp plant productivity of narrow-row crops by number of seeds, seeding rate and varietal factor

The purpose of research is to establish the dependence of seed productivity of hemp plants on variety and differentiated seeding rates.

The following methods were used to generalize the results of research and scientific substantiation of the purpose: general scientific (to determine the direction of research, planning and bookmarking the experiment); special (laboratory - to determine biometric indicators); mathematical and statistical (for processing experimental data).

Results. It is established that at increase of seeding rate to 1.8 million pieces / hectare in comparison with rate of 1.2 million pieces / hectare productivity of plants on quantity of seeds decreased by $25.4 \%$, for seeding rates of seeds of 2.4 million pieces / ha compared to the rate of 1.8 million pieces / ha - by $20.8 \%$, at the seeding rate of 3.0 million pieces / ha compared to the previous rate of 2.4 million pieces / ha - by $16.5 \%$ and at seeding rates of 3.6 million pieces / ha less seeds per plant was compared to the rate of 3.0 million pieces / ha - by $13.0 \%$. It was also found that hemp varieties differed significantly in productivity in the years of research at all seeding rates, in terms of the number of seeds per plant. On the average for factor $B$ in for three years of researches productivity of hemp varieties by parameters of seeds quantity per 1 plant was for varieties: YUSO-31 - 38 pieces, Gliana - 52 pieces and Glesiia - 56 pcs. This also confirms the effectiveness at the level of DNA structure, as a biological factor which includes modern varieties of hemp in the management of seed productivity of plants. 
Conclusions. The average experiment for factor $A$ in accordance with the specified seeding rates of $1.2 ; 1.8 ; 2.4$ 3.0 and 3.6 million pieces / ha, the indicators are $74.8 ; 55.8$; $44.2 ; 36.9 ; 32.1$ pieces of seeds per 1 plant. The largest number of seeds per 1 plant with a row spacing of $15 \mathrm{~cm}$ for all seeding rates of 1.2 million pieces / ha; 1.8; 2.4;
3.0 and 3.6 million pieces / ha were provided by the Glesiia hemp variety, the second most productive Gliana variety, and the lowest productivity was provided by the YUSO31 hemp variety.

Key words: hemp, number of seeds, seeding rate, variety, row spacing, productivity management. 